$$
\begin{array}{r|l}
\text { Jurnal Sains Komputer dan Teknologi Informasi } & \text { Page } \\
\text { E- ISSN: 2655-7460. Volume } 2 \text { Issue 2, Mei 2020 } & 12-21
\end{array}
$$

\title{
PENGUKURAN TINGKAT KESIAPAN APARATUR DAN MASYARAKAT KELURAHAN OEBUFU DALAM PENERAPAN PEMERINTAHAN DIGITAL MELAYANI
}

\author{
Fransiskus Mario Hartono Tjiptabudi ${ }^{1}$ \\ ${ }^{1)}$ Program Studi Sistem Informasi \\ Sekolah Tinggi Manajemen Informatika Komputer (STIKOM) Uyelindo \\ Jl. Perintis Kemerdekaan I, Kota Kupang, Nusa Tenggara Timur \\ Email: tjiptabudifrans@gmail.com
}

\begin{abstract}
$\underline{\text { Abstrak }}$
Digital serving government (Dilan - Digital Melayani) adalah proses layanan publik berbasis digital yang diluncurkan oleh pemerintah seiring dengan meningkatnya keterbukaan dan kecepatan dalam mengakses layanan informasi untuk mewujudkan tata kelola yang baik. Oleh karena itu, penerapan teknologi informasi merupakan ujung tombak implementasi Dilan. Masalahnya adalah apakah aparat pemerintah siap atau tidak di tingkat terendah (desa) dan masyarakat sendiri dalam memanfaatkan teknologi informasi. Penelitian ini bertujuan untuk mengukur kesiapan aparat dan masyarakat Desa Oebufu, Kota Kupang, Nusa Tenggara Timur jika teknologi informasi diterapkan dalam proses pelayanan yang dilakukan di desa. Metode pengumpulan data yang digunakan adalah observasi, wawancara, kuesioner, dan studi literatur. Khusus untuk kuesioner yang disiapkan mengacu pada kerangka STOPE yang telah disesuaikan dengan responden yaitu seluruh aparat desa serta sampel dari orang-orang yang dipilih secara acak. Hasil penelitian menunjukkan bahwa aparat dan masyarakat siap menerapkan teknologi informasi sebagai wujud dari pemerintahan Dilan yang diluncurkan dalam rangka mewujudkan tata pemerintahan yang baik.
\end{abstract}

Kata kunci: Digital serving government, Dilan, good governance, e-readiness, STOPE.

\begin{abstract}
$\underline{\text { ABSTRACT }}$
Digital serving government (Dilan - Digital Melayani) is a digital-based public service process that is launched by the government along with the increasing openness and speed in accessing information services in order to realize good governance. Therefore, the application of information technology is a spearhead of the implementation of Dilan. The problem is whether the government apparatuses are ready or not at the lowest level (village) and the people themselves in utilizing the information technology. This study aims to measure the e-readiness of the apparatus and people of Oebufu Village, Kupang City, East Nusa Tenggara if information technology is applied in the service process carried out in the village. Data collection methods used were observation, interviews, questionnaires and literature study. Specifically for the questionnaire prepared referring to the STOPE framework that has been adapted to the respondent namely the entire village apparatus as well as samples from randomly selected people. The results showed that the apparatus and the public are ready in implementing information technology as a manifestation of the Dilan government that was launched in order to realize good governance.
\end{abstract}

Keywords: Digital serving government, Dilan, good governance, e-readiness, STOPE.

\section{PENDAHULUAN}

Teknologi informasi berperan besar dalam proses kerja instansi pemerintahan seiring dengan kebutuhan pelayanan terhadap masyarakat yang berkualitas, cepat dan tepat agar tercipta tata kelola pemerintahan yang baik (good governance). Sujata et al (2002) berpendapat bahwa bentukbentuk pelayanan aparat pemerintah yang menciptakan suasana kondusif dengan masyarakat maka dapat dikategorikan sebagai keadaan yang mengarah pada terselenggaranya asas-asas good governance.

Good governance sendiri sangat penting dalam pelaksanaan pelayanan publik untuk meningkatkan kinerja aparatur negara. Hal ini karena pemerintah merancang konsep prinsip-prinsip good governance untuk meningkatkan potensi perubahan dalam birokrasi agar mewujudkan pelayanan publik yang lebih baik, di samping itu masyarakat 
Fransiskus Mario Hartono Tjiptabudi. Pengukuran Tingkat Kesiapan Aparatur Dan 2020
Masyarakat Kelurahan Oebufu Dalam Penerapan Pemerintahan Digital Melayani.

masih menganggap pelayanan publik yang dilaksanakan oleh birokrasi pasti cenderung lamban, tidak profesional, dan biayanya mahal (Maryam, 2016).

Selain itu, sesuai dengan Undang-Undang Nomor 5 Tahun 2014 tentang Aparatur Sipil Negara tertulis jelas bahwa kinerja instansi yang baik dapat mencerminkan kualitas pemerintahan yang semakin maju dan berkembang dengan berbagai kemudahan dalam melaksanakan aktivitas fungsi kerja maupun tanggung jawab instansi, yang mana dalam hal ini dapat dengan cepat dan tepat mengambil keputusan untuk memajukan kinerjanya.

Masih dalam UU yang sama, khususnya pada susunan peraturan untuk kinerja sistem kepemerintahan Negara Kesatuan Republik Indonesia dituliskan bahwa kinerja instansi yang terbaik dapat mencerminkan kualitas pemerintahan yang semakin maju dan berkembang dengan berbagai kemudahan dalam melaksanakan aktivitas fungsi kerja maupun tanggung jawab instansi, dimana dalam hal ini dapat dengan cepat dan tepat mengambil keputusan untuk memajukan kinerjanya. Maka setiap instansi pemerintah dituntut untuk dapat mengelola dengan baik sistem kerja yang tengah dijalankan, terutama dalam hal pengelolaan informasi secara lengkap, terstruktur, serta transparan kepada masyarakatnya sehingga kebutuhan akan informasi yang dibutuhkan oleh setiap pihak yang berkepentingan dapat terpenuhi dengan baik, lengkap, cepat serta dapat ditemukan dimana saja dan kapan saja.

Oleh karena itu, implementasi teknologi informasi sangat penting, karena melalui implementasi teknologi informasi dapat memberikan kontribusi yang berarti dalam meningkatkan kinerja instansi terkait. Hal tersebutlah yang mendasari dicetuskannya pemerintahan "Dilan" atau digital melayani oleh pemerintah saat ini guna memenuhi asas-asas good governance.

Permasalahan yang terjadi adalah selain membutuhkan perencanaan yang matang serta anggaran yang tidak sedikit, kesiapan SDM-lah yang menjadi permasalahan yang paling menonjol. Jika berbicara tentang pelayanan digital, maka yang menjadi faktor SDMnya bukan hanya dari segi aparatur pada setiap level pemerintahan saja, tetapi juga masyarakat itu sendiri. Oleh karena itu, sebelum mengimplementasikan teknologi informasi guna mendukung pemerintahan Dilan, perlu dilakukan pengukuran kesiapan dari aparatur maupun masyarakat agar implementasi tersebut benar-benar bermanfaat dan memberikan dampak yang positif.

\section{TINJAUAN PUSTAKA}

\subsection{Pemanfaatan TIK dalam Pemerintahan}

Peranan teknologi informasi dan komunikasi dalam menunjang sistem operasional dan manajerial pada instansi pemerintahan dewasa ini dirasakan semakin penting. Mengingat akan pentingnya fungsi pengelolaan data dan informasi ini, terutama untuk mendukung kegiatan-kegiatan di instansi pemerintah maka wajar kalau pemerintah berupaya untuk menempatkan pengelolaan data dan informasi ini pada tempat yang setara dan sama pentingnya dengan pengelolaan sumberdaya lainnya, seperti halnya sumberdaya manusia, keuangan, waktu dan yang lainnya. Sistem informasi kini telah menjadi kerangka dasar bagi semua aktifitas pemerintahan dan memungkinkan bagi fungsi manajerial dalam melakukan upaya pengelolaan sumber daya yang dimiliki secara lebih efisien dan efektif (Amri, 2016).

Berdasarkan laporan OECD (The Organisation for Economic Co-operation and Development) dalam Praditya (2014), diketahui bahwa penggunaan TIK oleh pemerintahan memunculkan beberapa keuntungan, yakni:

a. Meningkatkan efisiensi, penggunaan TIK dapat meningkatkan efisiensi dalam berbagi data atau informasi di dalam maupun antarpemerintahan. Penggunaan TIK juga dapat meningkatkan efisiensi dalam pengumpulan (collecting) dan penyampaian (transmission) data, penyediaan informasi dan komunikasi. Begitu pula dalam memroses tugas dan operasi administrasi publik.

b. Meningkatkan pelayanan, penggunaan TIK dapat meningkatkan pelayanan terhadap masyarakat. Dalam menggunakan layanan publik, masyarakat tidak perlu mengetahui struktur dan hubungan kompleks dibalik layanan yang diberikan oleh pemerintah.

c. Membantu mencapai suatu kebijakan tertentu, penggunaan TIK dapat membantu menyosialisasikan kebijakan pemerintah kepada masyarakat sehingga pihak-pihak terkait dapat berbagi ide dan informasi terkait dengan suatu kebijakan tertentu.

d. Membantu kontribusi terhadap kebijakan ekonomi, penggunaan TIK dalam e-government dapat mengurangi korupsi, meningkatkan keterbukaan dan kepercayaan terhadap pemerintah. Pemerintah juga dapat melakukan penghematan melalui proses administrasi dan penyediaan informasi berbasis TIK. Begitu pula dengan kegiatan ekonomi di desa/kelurahan berbasis TIK (e-commerce maupun e-business) dapat didukung dengan penggunaan TIK.

e. Meningkatkan kontribusi terhadap reformasi, penggunaan TIK telah mengubah atau mereformasi berbagai bidang, seperti: memperbaiki transparansi dan fasilitasi berbagi informasi.

f. Meningkatkan kepercayaan antara pemerintah dengan masyarakatnya, penggunaan TIK dapat meningkatkan good governance melalui peningkatan transparansi, mengurangi korupsi sehingga dapat meningkatkan kepercayaan masyarakat terhadap penyelenggara pemerintah. Begitu pula jika aspirasi dan pendapat masyarakat dapat difasilitasi ataupun ditampung dalam media berbasis TIK yang digunakan oleh pemerintah. 


$$
\begin{array}{r|l}
\text { Jurnal Sains Komputer dan Teknologi Informasi } & \text { Page } \\
\text { E-ISSN: 2655 7460. Volume } 2 \text { Issue 2, Mei 2020 } & 12 \sim 21 \\
\hline
\end{array}
$$

\subsection{Good Governance}

Konsep good governance muncul karena adanya ketidakpuasan pada kinerja pemerintahan yang selama ini dipercaya sebagai penyelenggara urusan publik. Menerapkan praktik good governance dapat dilakukan secara bertahap sesuai dengan kapasitas pemerintah, masyarakat sipil, dan mekanisme pasar. Salah satu pilihan strategis untuk menerapkan good governance di

Indonesia adalah melalui penyelenggaraan pelayanan publik.

Kunci utama keberhasilan penyelengaraan pemerintahan adalah good governance yaitu paradigma, sistem dan proses penyelenggaraan pemerintahan dan pembangunan yang mengindahkan prinsip-prinsip supremasi hukum, kemanusiaan, keadilan, demokrasi, partisipasi, transparansi, profesionalitas, dan akuntabilitas ditambah dengan komitmen terhadap tegaknya nilai dan prinsip "desentralisasi, daya guna, hasil guna, pemerintahan yang bersih, bertanggungjawab, dan berdaya saing (Amri, 2016).

Penerapan prinsip-prinsip good governance sangat penting dalam pelaksanaan pelayanan publik untuk meningkatkan kinerja aparatur negara. Hal ini karena pemerintah merancang konsep prinsip-prinsip good governance untuk meningkatkan potensi perubahan dalam birokrasi agar mewujudkan pelayanan publik yang lebih baik, di samping itu masyarakat masih menganggap pelayanan publik yang dilaksanakan oleh birokrasi pasti cenderung lamban, tidak profesional, dan

biayanya mahal.

Menurut Sadjjono (2005), good governance mengandung arti kegiatan suatu lembaga pemerintah yang dijalankan berdasarkan kepentingan rakyat dan norma yang berlaku untuk mewujudkan cita-cita negara. Menurut LAN \& BPKP (2005) yang dimaksud dengan good governance adalah bagaimana pemerintah berinteraksi dengan masyarakat dan mengelola sumber-sumber daya dalam pembangunan. Peraturan Pemerintah Nomor 101 Tahun 2000, merumuskan arti good governance sebagai kepemerintahan yang mengembangkan dan menerapkan prinsip-prinsip profesionalitas, akuntabilitas, transparansi, pelayanan prima, demokrasi, efisiensi, efektivias, supremasi hukum dan dapat diterima oleh seluruh masyarakat.

Dalam Peraturan Pemerintah Nomor 101 Tahun 2000, prinsip-prinsip kepemerintahan yang baik terdiri atas:

a. Profesionalitas, meningkatkan kemampuan dan moral penyelenggara pemerintahan agar mampu memberikan pelayanan yang mudah, cepat, tepat, dengan biaya terjangkau.

b. Akuntabilitas, meningkatkan akuntabilitas para pengambil keputusan dalam segala bidang yang menyangkut kepentingan masyarakat.

c. Transparansi, menciptakan kepercayaan timbal balik antara pemerintah dan masyarakat melalui penyediaan informasi dan menjadi kemudahan di dalam memperoleh informasi yang akurat dan memadai.

d. Pelayanan prima, penyelenggaraan pelayanan publik yang mencakup prosedur yang baik, kejelasan tarif, kepastian waktu, kemudahan akses, kelengkapan sarana dan prasarana serta pelayanan yang ramah dan disiplin.

e. Demokrasi dan partisipasi, mendorong setiap warga untuk mempergunakan hak dalam menyampaikan pendapat dalam proses pengambilan keputusan, yang menyangkut kepentingan masyarakat baik secara langsung maupun tidak langsung.

f. Efisiensi dan efektivitas, menjamin terselenggaranya pelayanan terhadap masyarakat dengan menggunakan sumber daya yang tersedia secara optimal dan bertanggung jawab.

g. Supremasi hukum dan dapat diterima oleh seluruh masyarakat, mewujudkan adanya penegakkan hukum yang adil bagi semua pihak tanpa pengecualian, menjunjung tinggi HAM dan memperhatikan nilai-nilai yang hidup dalam masyarakat.

Menurut United Nations Development Program (UNDP) terdapat 14 prinsip good governance, yaitu:

a. Wawasan ke depan (visionary);

b. Keterbukaan dan transparansi (openess and transparency);

c. Partisipasi masyarakat (participation);

d. Tanggung gugat (accountability);

e. Supremasi hukum (rule of law);

f. Demokrasi (democracy);

g. Profesionalisme dan kompetensi (profesionalism and competency);

h. Daya tanggap (responsiveness);

i. Keefisienan dan keefektivan (efficiency and effectiveness);

j. Desentralisasi (decentralization)

k. Kemitraan dengan dunia usaha swasta dan masyarakat (private sector and civil society partnership);

I. Komitmen pada pengurangan kesenjangan (commitment to reduce inequality);

m. Komitmen pada lingkungan hidup (commitment to environmental protection);

n. Komitmen pasar yang fair (commitment to fair market). Keempat belas prinsip good governance tersebut secara singkat dapat dijelaskan sebagai berikut:

a. Tata pemerintahan yang berwawasan ke depan (visi strategis), semua kegiatan pemerintah di berbagai bidang dan tingkatan seharusnya didasarkan pada visi dan misi yang jelas dan jangka waktu pencapaiannya serta dilengkapi strategi implementasi yang tepat sasaran, manfaat dan berkesinambungan.

b. Tata pemerintahan yang bersifat terbuka (transparan), wujud nyata prinsip tersebut antara lain dapat dilihat 
Fransiskus Mario Hartono Tjiptabudi. Pengukuran Tingkat Kesiapan Aparatur Dan 2020

Masyarakat Kelurahan Oebufu Dalam Penerapan Pemerintahan Digital Melayaní.

apabila masyarakat mempunyai kemudahan untuk mengetahui serta memperoleh data dan informasi tentang kebijakan, program dan kegiatan aparatur pemerintah, baik yang dilaksanakan di tingkat pusat maupun daerah.

c. Tata pemerintahan yang mendorong partisipasi masyarakat, masyarakat yang berkepentingan ikut serta dalam proses perumusan dan/atau pengambilan keputusan atas kebijakan publik yang diperuntukkan bagi masyarakat, sehingga keterlibatan masyarakat sangat diperlukan pada setiap pengambilan kebijakan yang menyangkut masyarakat luas.

d. Tata pemerintahan yang bertanggungjawab/bertanggung gugat (akuntabel), instansi pemerintah dan para aparaturnya harus dapat mempertanggungjawabkan pelaksanaan kewenangan yang diberikan sesuai dengan tugas pokok dan fungsinya. Demikian halnya dengan kebijakan, program, dan kegiatan yang dilakukannya dapat dipertanggungjawabkan.

e. Tata pemerintahan yang menjunjung supremasi hukum, wujud nyata prinsip ini mencakup upaya penuntasan kasus KKN dan pelanggaran HAM, peningkatan kesadaran HAM, peningkatan kesadaran hukum, serta pengembangan budaya hukum. Upaya-upaya tersebut dilakukan dengan menggunakan aturan dan prosedur yang terbuka dan jelas, serta tidak tunduk pada manipulasi politik.

f. Tata pemerintahan yang demokratis dan berorientasi pada konsensus, perumus kebijakan pembangunan baik di pusat maupun daerah dilakukan melalui mekanisme demokrasi, dan tidak ditentukan sendiri oleh eksekutif. Keputusan-keputusan yang diambil antara lembaga eksekutif dan legislatif harus didasarkan pada konsensus agar setiap kebijakan publik yang diambil benar-benar merupakan keputusan bersama.

g. Tata pemerintahan yang berdasarkan profesionalitas dan kompetensi, wujud nyata dari prinsip profesionalisme dan kompetensi dapat dilihat dari upaya penilaian kebutuhan dan evaluasi yang dilakukan terhadap tingkat kemampuan dan profesionalisme sumber daya manusia yang ada, dan dari upaya perbaikan atau peningkatan kualitas sumber daya manusia.

h. Tata pemerintahan yang cepat tanggap (responsif), aparat pemerintahan harus cepat tanggap terhadap perubahan situasi/kondisi mengakomodasi aspirasi masyarakat, serta mengambil prakarsa untuk mengatasi berbagai masalah yang dihadapi masyarakat.

i. Tata pemerintahan yang menggunakan struktur dan sumber daya secara efisien dan efektif, pemerintah pusat maupun daerah dari waktu ke waktu harus selalu menilai dukungan struktur yang ada, melakukan perbaikan struktural sesuai dengan tuntutan perubahan seperti menyusun kembali struktur kelembagaan secara keseluruhan, menyusun jabatan dan fungsi yang lebih tepat, serta selalu berupaya mencapai hasil yang optimal dengan memanfaatkan dana dan sumber daya lainnya yang tersedia secara efisien dan efektif.

j. Tata pemerintahan yang terdesentralisasi, pendelegasian tugas dan kewenangan pusat kepada semua tingkatan aparat sehingga dapat mempercepat proses pengambilan keputusan, serta memberikan keleluasaan yang cukup untuk mengelola pelayanan publik dan mensukseskan pembangunan di pusat maupun di daearah.

k. Tata pemerintahan yang mendorong kemitraan dengan dunia usaha, swasta dan masyarakat, pembangunan masyarakat madani melalui peningkatan peran serta masyarakat dan sektor swasta harus diberdayakan melalui pembentukan kerjasama atau kemitraan antara pemerintah, swasta, dan masyarakat. Hambatan birokrasi yang menjadi rintangan terbentuknya kemitraan yang setara harus segera diatasi dengan perbaikan sistem pelayanan kepada masyarakat dan sektor swasta serta penyelenggaraan pelayanan terpadu.

I. Tata pemerintahan yang memiliki komitmen pada pengurangan kesenjangan, pengurangan kesenjangan dalam berbagai bidang baik antara pusat dan daerah maupun antar daerah secara adil dan proporsional merupakan wujud nyata prinsip pengurangan kesenjangan. Hal ini juga mencakup upaya menciptakan kesetaraan dalam hukum (equity of the law) serta mereduksi berbagai perlakuan diskriminatif yang menciptakan kesenjangan antara laki-laki dan perempuan dalam kehidupan bermasyarakat.

m. Tata pemerintahan yang memiliki komitmen pada lingkungan hidup, daya dukung lingkungan semakin menurun akibat pemanfaatan yang tidak terkendali. Kewajiban penyusunan analisis mengenai dampak lingkungan secara konskuen, penegakkan hukum lingkungan secara konsisten, pengaktifan lembagalembaga pengendali dampak lingkungan, serta pengelolaan sumber daya alam secara lestari merupakan contoh perwujudan komitmen pada lingkungan hidup.

o. Tata pemerintahan yang memiliki komitmen pada pasar, pengalaman telah membuktikan bahwa campur tangan pemerintah dalam kegiatan ekonomi seringkali berlebihan sehingga akhirnya membebani anggaran belanja dan bahkan merusak pasar. Upaya pengaitan kegiatan ekonomi masyarakat dengan pasar baik di dalam daerah maupun antara daerah merupakan contoh wujud nyata komitmen pada pasar. 


\section{Jurnal Sains Komputer dan Teknologi Informasi |Page \\ E- ISSN: 2655-7460. Volume 2 Issue 2, Mei $2020 \mid 12$ 21}

\subsection{Kerangka Kerja STOPE}

Kerangka kerja STOPE adalah pengembangan dari metode Linstone yang terdiri dari 3 (tiga) domain utama yaitu technology, organization, dan people guna meneliti perkembangan teknologi di masyarakat dengan. Bakry (penggagas kerangka STOPE) menambahkan dua item, yaitu strategy dan environment, sehingga menjadi STOPE (Al-osaimi, Alheraish dan Bakry, 2006) yang terlihat pada gambar 1 .

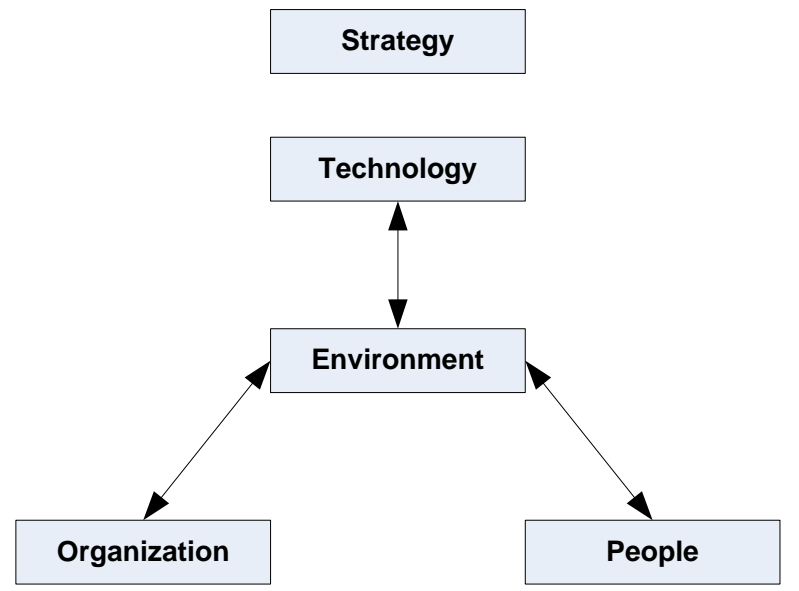

Gambar 1. Domain STOPE

Kerangka kerja STOPE terdiri dari 5 (lima) domain utama yaitu Strategy, Technology, Organization, People, dan Environment. Domain Strategy terdiri dari isu IT Leadership dan Future Plans. Domain Technology terdiri dari IT Provisioning, IT Basic Infrastructure, IT e-Services Infrastructure dan IT Support. Domain Organization terdiri dari isu IT Regulation, IT Cooperation, dan IT Management. Domain People terdiri dari isu IT Jobs, IT Awareness, IT Performance dan IT Education. Domain Environment terdiri dari isu Management, Knowledge, General Infrastructure, dan Economy. Gambar berikut menunjukkan domain dan isu pada kerangka kerja STOPE.
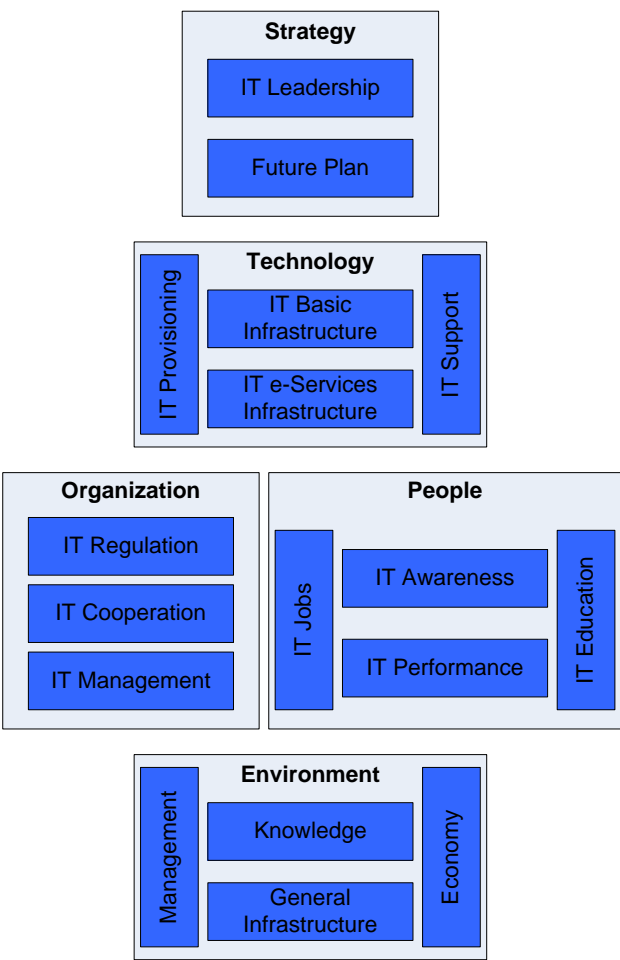

Gambar 2. Domain dan sub domain STOPE

a. Domain Strategy mengintegrasikan faktor-faktor yang berkaitan dengan tujuan kedepan, komitmen dan rencana terhadap pengembangan dan pemanfaatan teknologi informasi. Dua isu yang dianggap terkait dengan domain ini adalah "Leadership" dan "Future Development Plans".

b. Domain Technology mengintegrasikan faktor-faktor yang berkaitan dengan keadaan isu terkait dengan fasilitas teknologi informasi saat ini. Empat isu yang dianggap terkait dengan domain ini adalah "IT Basic Infrastructure", "IT e-services infrastructure", "IT Provisioning" dan "IT support".

c. Domain Organization mengintegrasikan faktor-faktor yang berkaitan dengan keadaan isu terkait dengan regulasi dan manajemen teknologi informasi saat ini. Tiga isu yang dianggap terkait dengan domain ini adalah "IT Regulation", "IT Cooperation", dan "IT Management".

d. Domain People mengintegrasikan faktor-faktor yang berkaitan dengan keadaan isu terkait dengan pengguna dan keterampilan teknologi informasi saat ini. Empat isu yang dianggap terkait dengan domain ini adalah "IT Awareness", "IT Education and Training", "IT Qualifications and Jobs", dan "IT Performance and Satisfaction".

e. Domain Environment mengintegrasikan faktor-faktor yang berkaitan dengan keadaan saat ini isu-isu dasar 
Masyarakat Kelurahan Oebufu Dalam Penerapan Pemerintahan Digital Melayaní.

bukan teknologi informasi yang mempengaruhi keadaan teknologi informasi saat ini. Empat isu yang dianggap terkait dengan domain ini adalah "Knowledge",
"Resources and Economy", "Management", dan "Non-IT Infrastructure".

Berikut detail dari Gambar 2 yang dijelaskan secara rinci pada Tabel 1:

Tabel 1. Item domain, sub-domain, dan sub-sub-domain pada kerangka kerja STOPE

(Al-osaimi, Alheraish dan Bakry, 2006)

\section{STRATEGY}

"Directions, commitmens and plans toward ICT development and utilization"

$$
\text { Vision }
$$

ICT-Leadership

Government Support

Commitment

IT Managers / Responsibilities

Technology ICT Plan

Future Plan

Organization Plan

ICT HR Plan

Related Non-ICT Plans: Environment

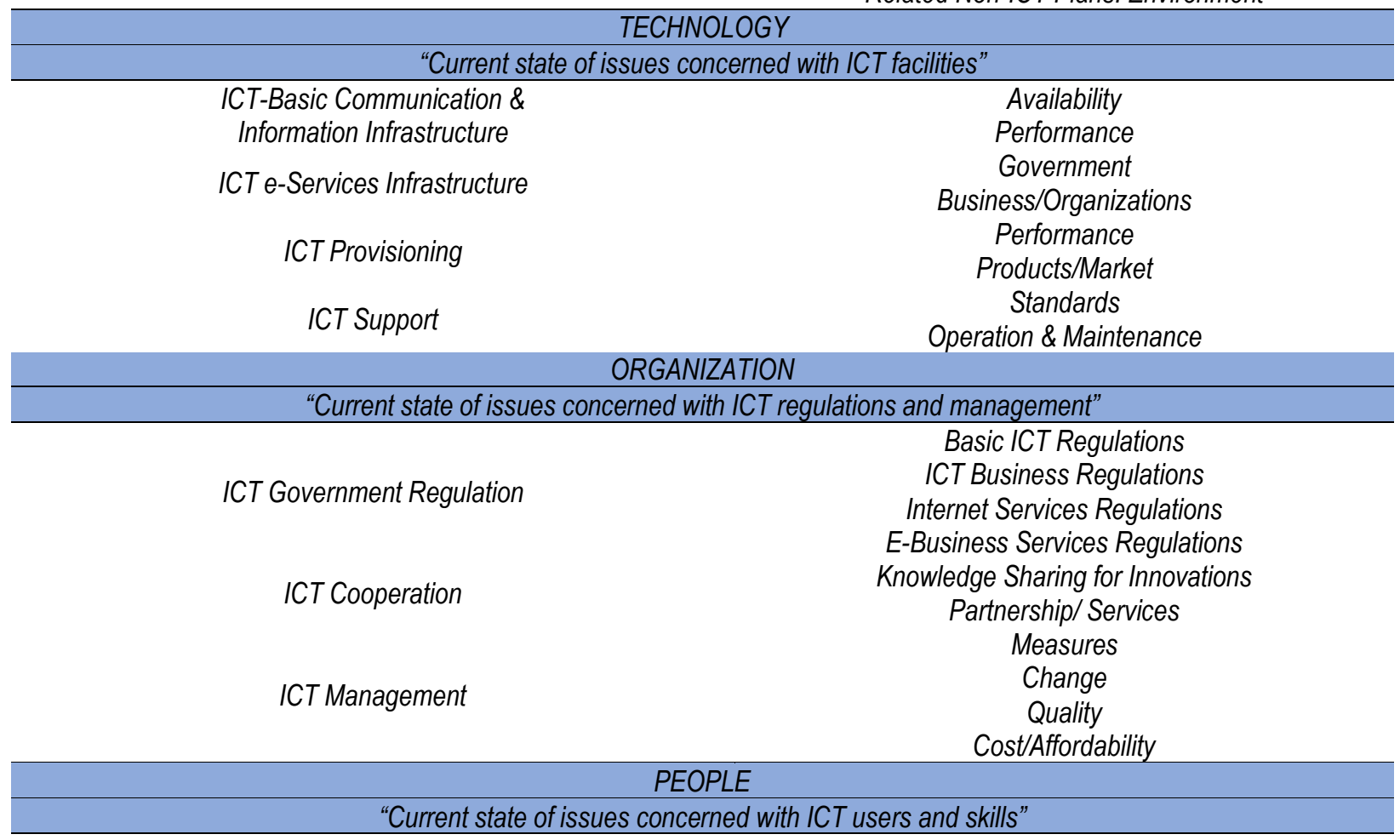

ICT Awareness

ICT Education and Training

ICT Qualifications and Jobs

Management of ICT Skills
ICT Literacy

Education System Support

Media Support

ICT Qualifications

E-Education/e-Learning

Jobs

Skills

Performance

Satisfaction 


$$
\begin{array}{r|l}
\text { Jurnal Sains Komputer dan Teknologi Informasi } & \text { Page } \\
\text { E- ISSN: 2655-7460. Volume } 2 \text { Issue 2, Mei 2020 } & 12-21
\end{array}
$$

Knowledge

Resources and Economy

Organization

Infrastructure

\section{Culture}

Education \& Training

Natural Resource

Revenues/Profitability

Trade

Income

Government Regulation

Cooperation

Management

Basic services:

Electricity/Transportation/Portal

System/Health Care
Setiap domain, sub-domain, dan indikator diukur secara individual dengan cara scaling menggunakan lima skala evaluasi e-readiness untuk mendapatkan nilai measure $(m)$.

Tabel 2. Skala evaluasi kesiapan

\begin{tabular}{cccccc}
\hline Skor & 0 & 1 & 2 & 3 & 4 \\
\hline Ket & None & Poor & Average & Good & Excellent \\
\hline
\end{tabular}

Setiap domain, sub-domain, dan indikator diukur nilai bobot (w) secara individual dengan cara menghitung nilai ratarata bobot domain, sub-domain, dan indikator yang ingin diukur.

$$
\begin{gathered}
W_{\text {domain }}=\frac{\text { domain }_{1}}{\sum_{1}^{5} \text { domain }} \\
W_{\text {subdomain }}=\frac{\text { subdomain }}{\sum_{1}^{n} \text { subdomain }} \\
W_{\text {indikator }}=\frac{\text { indikator }}{\sum_{1}^{5} \text { indikator }}
\end{gathered}
$$

Setelah mendapatkan nilai bobot $(w)$ dan nilai measure $(m)$, tahapan selanjutnya adalah menghitung nilai overall STOPE's Grade dengan rumus sebagai berikut:

STOPE $=m x W$

yang mana $m$ adalah nilai measure dan $W$ adalah nilai bobot.

\subsection{Penelitian Terkait}

Penelitian tentang analisis atau evaluasi kesiapan (readiness) telah dilakukan oleh berbagai peneliti. Analisis kesiapan pada sektor pemerintahan yang dilakukan dengan berbagai metode dan pendekatan penting dilakukan karena kesiapan sangat menentukan kesuksesan implementasi TIK dalam bidang pemerintahan dan pencapaian sasarannya. Salah satunya adalah penelitian yang dilakukan oleh Cahyati (2019) yang mengukur kesiapan masyarakat Jember dalam menerapkan aplikasi WAR berdasarkan kerangka kerja
STOPE. Aplikasi WAR (We Are Ready) sendiri merupakan layanan pengaduan masyarakat kepada Polres Jember secara realtime. Hasil dari penelitian tersebut menunjukkan bahwa kerangka kerja STOPE dapat digunakan untuk mengukur kesiapan masyarakat Jember yang secara umum belum siap untuk menerapkan aplikasi WAR.

Penelitian analisis kesiapan yang lainnya dengan memanfaatkan kerangka kerja STOPE dilakukan oleh Susanto (2014). STOPE digunakan untuk menganalisis kesiapan pemda Kabupaten Gunung Kidul dalam menerima pengalihan Pajak Bumi dan Bangunan (PBB). Peneliti melakukan analisis terhadap 5 domain, 15 sub-domain dan 59 sub-sub-domain, yang memperoleh hasil analisis kesiapan berada pada skala 4 atau sangat siap.

Berdasarkan penelitian terkait yang telah dibahas, pemilihan kerangka kerja STOPE untuk melakukan analisis atau evaluasi tingkat kesiapan lebih dikarenakan oleh fleksibilitas dalam pemilihan dan penggunaan item-itemnya disesuaikan dengan kebutuhan objek penelitian.

\section{METODE PENELITIAN}

\subsection{Metode Pengumpulan Data}

Pengumpulan data yang dilakukan dalam penelitian ini adalah dengan cara:

a. Observasi

Pengumpulan data dengan melakukan pengamatan secara langsung terhadap objek penelitian dan mencatat halhal penting yang berhubungan dengan subjek dan objek penelitian.

b. Wawancara

Melakukan kegiatan tanya jawab secara tatap muka langsung dengan narasumber antara lain Lurah, aparatur kelurahan dan masyarakat Kelurahan Oebufu.

\section{c. Kuesioner}

Alat survei yang terdiri atas serangkaian pertanyaan tertulis, bertujuan mendapatkan tanggapan dari kelompok orang terpilih.

\section{d. Studi pustaka}


Masyarakat Kelurahan Oebufu Dalam Penerapan Pemerintahan Digital Melayaní.

Mencari literatur atau sumber pustaka pendukung penelitian dan memberikan informasi yang memadai serta membantu mempertegas teori-teori yang ada.

\subsection{Tahapan Penelitian}

Tahapan-tahapan yang dilalui oleh peneliti dimulai dari permulaan pengumpulan data sampai kesimpulan yang membentuk sebuah alur yang sistematis. Metodologi penelitian ini digunakan sebagai pedoman peneliti dalam pelaksanaan penelitian agar hasil yang dicapai sesuai dengan tujuan yang telah ditentukan sebelumnya. Berikut ini flowchart tahapan penelitian:

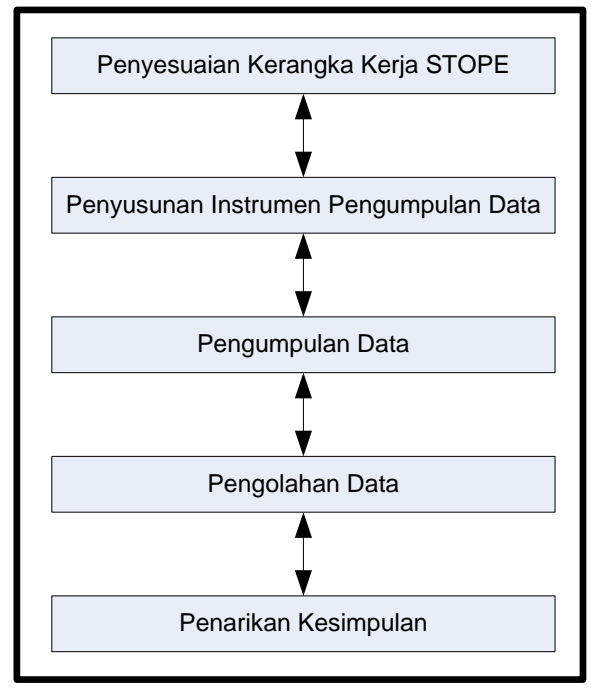

Gambar 3. Tahapan penelitian

Karena fleksibilitasnya maka penerapan kerangka kerja STOPE pada penelitian ini perlu disesuaikan. Tahapan pertama penelitian yaitu membuat modifikasi atau penyesuaian kerangka tersebut yang akan menjadi dasar dalam penyusunan instrument pengumpulan data.
Tahap kedua yang dilakukan adalah menyusun itemitem pernyataan berdasarkan kerangka kerja STOPE yang telah disesuaikan dengan kebutuhan. Haislnya berupa sebuah instrumen pengumpulan data.

Instrumen tersebut kemudian dibagikan kepada responden untuk diberi tanggapan. Responden yang diambil menggunakan yeknik accidental sampling. Adapun hasil dari tahapan ini adalah kumpulan data yang bersifat kuantitatif.

Data yang dikumpulkan kemudian ditabulasi dan diolah. Pengolahan data ini dilakukan dengan melakukan perhitungan menggunakan rumus STOPE.

Tahap terakhir yang dilakukan yaitu penarikan kesimpulan terbagi atas 2 (dua) aktivitas yakni pemeringkatan data dan identifikasi rekomendasi berdasarkan peringkat data.

\section{HASIL DAN PEMBAHASAN}

\subsection{Populasi dan Sampel}

Populasi adalah seluruh data yang menjadi perhatian kita dalam suatu ruang lingkup dan waktu yang kita tentukan (Margono, 2004). Jadi populasi berhubungan dengan data, bukan manusianya. Kalau setiap manusia memberikan suatu data maka banyaknya atau ukuran populasi akan sama dengan banyaknya manusia.

Adapun untuk penelitian ini diketahui jumlah aparatur kelurahan sebanyak 16 orang, selain itu dari kalangan masyarakat Kelurahan Oebufu yang mana dalam laporan bulanan Kelurahan Oebufu berdasarkan sensus penduduk bulan Januari 2020 diketahui sebanyak 13.789 jiwa. Oleh karena jumlah populasi dalam penelitian ini yang cukup besar maka untuk mendapatkan jumlah sampel mengacu pada pernyataan Hair et al, (2010) bahwa banyaknya sampel sebagai responden harus disesuaikan dengan banyaknya indikator pertanyaan/pernyataan yang akan digunakan pada kuesioner, dengan asumsi $\mathrm{n} \times 5$ observed variable (indikator) sampai dengan $\mathrm{n} \times 10$ observed variable (indikator).

Maka pada penelitian ini jumlah item pernyataan yaitu sebanyak 25 item pernyataan yang digunakan untuk mengukur 5 variabel/dimensi, sehingga perhitungan untuk penentuan jumlah responden yang digunakan adalah 25 dikali 5 maka diperoleh jumlah 125 sebagai sampel minimum, 25 dikali 10 diperoleh sebanyak 250 sampel sebagai sampel maksimum. Dikarenakan pelaksanaan social distancing akibat pandemi Covid-19 maka diputuskan untuk menggunakan sampel minimum yakni sebanyak 125 orang sebagai responden dalam penelitian ini.

\subsection{Penggunaan Kerangka Kerja STOPE}

a. Penyesuaian domain dan sub-domain.

Instrumen penelitian yang akan dibagikan disusun berdasarkan kerangka kerja STOPE yang telah disesuaikan dengan keadaan. Adapun domain dan sub-domain yang digunakan pada penelitian ini adalah sebagai berikut: 


$$
\begin{array}{r|l}
\text { Jurnal Sains Komputer dan Teknologi Informasi } & \text { Page } \\
\text { E- ISSN: 2655-7460. Volume } 2 \text { Issue 2, Mei 2020 } & 12-21
\end{array}
$$

\begin{tabular}{|c|c|c|}
\hline No. & Domain & Sub-domain yang digunakan \\
\hline 1. & Strategy & $\begin{array}{l}\text { 1. ICT Leadership } \\
\text { 2. Future Plan }\end{array}$ \\
\hline 2. & Technology & $\begin{array}{l}\text { 1. ICT-Basic Communication } \\
\& \\
\text { Information Infrastructure }\end{array}$ \\
\hline 3. & Organization & $\begin{array}{l}\text { 1. ICT Government } \\
\text { Regulation } \\
\text { 2. ICT Cooperation }\end{array}$ \\
\hline 4. & People & 1. ICT Awareness \\
\hline 5. & Environment & $\begin{array}{l}\text { 1. Knowledge } \\
\text { 2. Organization } \\
\text { 3. Infrastructure }\end{array}$ \\
\hline
\end{tabular}

Tabel 3. Domain dan sub-domain yang dighunakan

b. Pengolahan data

Adapun hasil perhitungan dari 9 sub-domain yang

Diteliti dapat dilihat pada tabel berikut:

Tabel 4. Hasil perhitungan sub-domain

\begin{tabular}{llcc}
\hline No. & \multicolumn{1}{c}{ Sub-domain } & $\begin{array}{c}\text { Measure } \\
\text { (Skala 4) }\end{array}$ & $\%$ \\
\hline 1. & ICT Leadership & 2,53 & $85 \%$ \\
2. & Future Plan & 2,48 & $83 \%$ \\
3. & ICT-Basic Communication & 2,74 & $91 \%$ \\
& $\begin{array}{l}\text { \& Information } \\
\text { Infrastructure }\end{array}$ & & \\
4. & ICT Government & 2,18 & $72 \%$ \\
& Regulation & & \\
5. & ICT Cooperation & 2,4 & $80 \%$ \\
6. & ICT Awareness & 2,6 & $87 \%$ \\
7. & Knowledge & 2,32 & $77 \%$ \\
8. & Organization & 2,45 & $82 \%$ \\
9. Infrastructure & 2,26 & $74 \%$ \\
\hline
\end{tabular}

Berdasarkan tabel 4 diketahui bahwa dari 9 sub-domain yang diukur dalam penelitian ini, yang memperoleh nilai tertinggi yaitu sub-domain infrastruktur dasar TIK dengan nilai measure 2,74 (91\%), sedangkan sub-domain dengan nilai measure terendah yaitu regulasi TIK dengan nilai 2,18 (72\%).

Untuk hasil perhitungan pada level domain disajikan pada tabel berikut:

Tabel 5. Hasil perhitungan domain

\begin{tabular}{llcc}
\hline No. & Sub-domain & $\begin{array}{c}\text { Measure } \\
\text { (Skala 4) }\end{array}$ & $\%$ \\
\hline 1. & Strategy & 2,45 & $82 \%$ \\
2. & Technology & 2,74 & $91 \%$ \\
3. & Organization & 2,29 & $76 \%$ \\
4. & People & 2,6 & $87 \%$ \\
5. & Environment & 2,34 & $78 \%$ \\
& STOPE & 2,52 & $85 \%$ \\
\hline
\end{tabular}

Berdasarkan hasil perhitungan evaluasi domain, nilai yang diperoleh oleh domain Technology yaitu sebesar 2,74 $(91 \%)$ yang merupakan nilai tertinggi dari kelima domain sedangkan nilai terendah yaitu pada domain Organization yang memperoleh nilai sebesar 2,29 (76\%).

Nilai evaluasi yang diperoleh merupakan gabungan dari nilai kelima domain dan dianggap dapat mewakili kesiapan aparatur dan masyarakat dalam penerapan teknologi informasi dalam rangka pelaksanaan pemerintahan Dilan. Hasil perhitungan secara keseluruhan dengan menggunakan rumus matematis seperti tampak pada tabel 5 diketahui bahwa nilai STOPE sebesar 2,52 (82\%).

\subsection{Penarikan Kesimpulan}

a. Pemeringkatan data

Adapun hasil pemeringkatan level sub-domain sebagai berikut:

\begin{tabular}{|c|c|c|c|}
\hline No. & Sub-domain & Peringkat & Keterangan \\
\hline 1. & ICT Leadership & 4 & Sangat siap \\
\hline 2. & Future Plan & 4 & Sangat siap \\
\hline 3. & $\begin{array}{l}\text { ICT-Basic } \\
\text { Communication \& } \\
\text { Information } \\
\text { Infrastructure }\end{array}$ & 4 & Sangat siap \\
\hline 4. & $\begin{array}{l}\text { ICT Government } \\
\text { Regulation }\end{array}$ & 3 & Siap \\
\hline 5. & ICT Cooperation & 4 & Sangat siap \\
\hline 6. & ICT Awareness & 4 & Sangat siap \\
\hline 7. & Knowledge & 3 & Siap \\
\hline 8. & Organization & 4 & Sangat siap \\
\hline 9. & Infrastructure & 3 & Siap \\
\hline
\end{tabular}

Tabel 6. Pemeringkatan level sub-domain

Berdasarkan tabel 6 dapat diketahui hasil pemeringkatan pada level sub-domain. Dari 9 sub-domain yang dievaluasi, rata-rata berada pada peringkat 4 yakni pada kategori sangat siap. Terdapat 3 sub-domain yang berada pada peringkat 3 yaitu sud-domain infrastruktur dasar TIK, regulasi TIK, pengetahuan dan infrastruktur. Sedangkan hasil pemeringkatan pada level domain dan kerangka kerja STOPE yakni sebagai berikut:

\begin{tabular}{|c|c|c|c|}
\hline No. & Sub-domain & Peringkat & Keterangan \\
\hline 1. & Strategy & 4 & Sangat siap \\
\hline 2. & Technology & 4 & Sangat siap \\
\hline 3. & Organization & 3 & Siap \\
\hline 4. & People & 4 & Sangat siap \\
\hline \multirow[t]{2}{*}{5.} & Environment & 3 & Siap \\
\hline & STOPE & 4 & Sangat siap \\
\hline
\end{tabular}

Tabel 7. Pemeringkatan level domain

Tabel 7 diatas menunjukan peringkat dari 5 domain berdasarkan hasil perhitungan sebelumnya. Dari kelima domain terdapat 2 domain yang memperoleh nilai yang berada pada peringkat 3 (kategori siap) yaitu domain Organization dan Environment, sedangkan domain Strategy, Technology dan People memperoleh nilai yang berada pada peringkat 4 (kategori sangat siap). Masih berdasarkan tabel 7 , diketahui nilai kesiapan yang diperoleh pada level kerangka 
Fransiskus Mario Hartono Tjiptabudi. Pengukuran Tingkat Kesiapan Aparatur Dan 2020

Masyarakat Kelurahan Oebufu Dalam Penerapan Pemerintahan Digital Melayaní.

kerja STOPE berada pada peringkat 4 (kategori sangat siap). Hal tersebut menunjukan bahwa aparatur dan masyarakat Kelurahan Oebufu sangat siap (completely ready) untuk menerapkan teknologi informasi dalam rangka pelaksanaan pemerintahan Dilan.

b. Rekomendasi

Berdasarkan hasil perhitungan, walaupun mayoritas domain termasuk dalam kategori siap dan sangat siap bukan berarti bahwa tidak perlu dilakukan perubahan ke depannya. Oleh karena itu, terdapat beberapa hal yang dapat direkomendasikan guna menjadi dasar perbaikan ke depannya.

Diperlukan komitmen untuk peningkatan kerjasama dengan pihak-pihak yang kompeten dalam rangka implementasi teknologi informasi, misalnya saja dari kalangan akademisi untuk melakukan penelitian-penelitian dan juga sebagai konsultan. Perlu dilakukan studi yang dilihat dari berbagai aspek untuk menentukan teknologi yang tepat serta infrastruktur pendukung untuk digunakan.

Membuat rencana induk untuk implementasi teknologi informasi agar berjalan sesuai dengan yang diharapkan dalam berbagai bentuk, misalnya berupa sebuah kebijakan yang memuat mekanisme untuk mendorong aparatur maupun masyarakat untuk menggunakan teknologi informasi. Mutlak melakukan sosialisasi berupa pelatihan tentang implementasi teknologi informasi.

\section{KESIMPULAN DAN SARAN}

Pengukuran kesiapan pada penelitian ini menerapkan kerangka kerja STOPE yang telah disesuaikan, dengan 5 domain dan 9 sub-domain. Hasil penelitian menunjukan bahwa domain Strategy, Technology dan People berada pada peringkat 4 (kategori sangat siap). Domain lainnya yaitu Organization dan Environment berada pada peringkat 3 (kategori siap). Secara keseluruhan atau hasil perhitungan STOPE berada pada peringkat 4 (kategori sangat siap) untuk mengimplementasikan teknologi informasi dalam proses pelayanan pada kelurahan.

Walaupun tingkat kesiapan aparatur dan masyarakat Kelurahan Oebufu yang diukur pada penelitian ini termasuk dalam kategori sangat siap untuk mengimplementasi teknologi informasi dalam proses pelayanan, tetapi hal tersebut tidak mutlak menjamin bahwa pelaksanaan pemerintahan Dilan dapat terlaksana dengan baik. Hal tersebut dikarenakan oleh belum semua aspek (sub-domain) pada kerangka kerja STOPE yang diukur pada penelitian ini. Oleh karena itu, penting untuk melakukan perbaikan ke depannya sesuai dengan rekomendasi yang diberikan agar baik aparatur maupun masyarakat benar-benar siap dan didukung dengan segala infrastuktur yang tepat.

\section{ACKNOWLEDGEMENT}

Penulis mengucapkan terima kasih kepada Lurah, para aparatur dan masyarakat Kelurahan Oebufu, Kota Kupang, Nusa Tenggara Timur yang telah memberikan dukungan atas partisipasinya sebagai tempat dan responden penelitian.

\section{DAFTAR PUSTAKA}

Al-osaimi, K., Alheraish, A., \& Bakry, S. H, 2006. An Integrated STOPE Framework for e-Readiness Assessments. Proceeding of 18 th National Computer Conference. Computer Society, Saudi Arabia: Saudi.

Amri. 2016. Analisis Pemanfaatan Teknologi Informasi Dan Komunikasi Dalam Menunjang Terwujudnya Makassar Sebagai "Smart City". Jurnal Komunikasi KAREBA. Vol. 5 No.2.

Cahyati, RD. 2019. Evaluasi Kesiapan Masyarakat Jember Dalam Penerapan Aplikasi WAR (We Are Ready) Menggunakan Framework STOPE (Studi Kasus: Polres Jember). Universitas Jember.

Hair JF., Black W., Babin B., Anderson R. 2010. Multivariate Data Analysis. $7^{\text {th }}$ Edition. New York: Prentice Hall International, Inc.

LAN dan BPKP. 2000. Pelayanan Publik. Malang: CV Citra Malang.

Margono. 2004. Metodologi Penelitian Pendidikan. Jakarta: Rineka Cipta.

Maryam NS. 2016. Mewujudkan Good Governance Melalui Pelayanan Publik. Jurnal IImu Politik dan Komunikasi. Volume VI, No. 1.

Praditya D. 2014. Pemanfaatan Teknologi Informasi Dan Komunikasi (Tik) Di Tingkat Pemerintahan Desa. Jurnal Penelitian Komunikasi. Vol. 17 No.2.

Sadjijono. 2005. Fungsi Kepolisian dalam Pelaksanaan Good Governance. Sleman: LaksBang.

Susanto, H. 2014. Pendekatan Framework STOPE untuk Mengukur Kesiapan Pengalihan PBB pada Pemerintah Kabupaten Gunungkidul. JNTETI. Vol. 3, No. 2.

Sujata A., Masthuri B., Winarso, Fernandes DD. Widyawati S. 2002. Ombudsman Indonesia Masa Lalu, Sekarang, dan Masa Mendatang. Jakarta (ID): Komisi Ombudsman Nasional.

United Nations Development Programme. 1997. Governance for Sustainable Human Development : a UNDP Policy Document. New York: UNDP.

Peraturan Pemerintah (PP) Nomor 101 Tahun 2000 Tentang Pendidikan Dan Pelatihan Jabatan Pegawai Negeri Sipil.

Undang- Undang Republik Indonesia Nomor 5 Tahun 2014. 